\title{
Communicating World Heritage to global audiences of travelers. ECREA 2018 special panel report
}

Lorenzo Cantoni, USI - Università della Svizzera italiana, UNESCO Chair in ICT to develop and promote sustainable tourism in World Heritage Sites

Silvia De Ascaniis*, USI - Università della Svizzera italiana, UNESCO Chair in ICT to develop and promote sustainable tourism in World Heritage Sites

${ }^{*}$ Corresponding author: silvia.de.ascaniis@usi.ch

\section{Note}

Invited report for the Thematic Section on ECREA 2018 devoted to the $7^{\text {th }}$ European Communication Conference of the European Communication and Research Association (ECREA), held in Lugano from October $31^{\text {st }}$ to November $3^{\text {rd }}, 2018$.

The year 2018 has been designated as the European Year of Cultural Heritage. All EU countries - including Switzerland, which has joined the celebration with its own logo - committed themselves to support the organization of a series of initiatives and events across Europe, with the aim of "encouraging people to discover and engage with Europe's cultural heritage to reinforce a sense of belonging to a common European space" (http://europa.eu/ cultural-heritage $^{1}$ ).

Cultural heritage has a universal value: it permeates and shapes our identities and everyday lives, it creates a sense of belonging and communion, and is thus able to put into contact centres and peripheries. It takes different forms, from tangible assets like monuments, artifacts, archeological sites, up to intangible ones like practices, oral traditions, performing arts and traditional craftsmanship. In 1972, UNESCO adopted the "Convention Concerning the Protection of the World Cultural and Natural Heritage" - which has so far been signed by 193 State Parties - to urge awareness and action towards the protection of world heritage, against natural deterioration as well as intentional destruction. The 1972 Convention also includes natural sites, like landscapes and parks that represent value for humankind. In 2003, then,

1 Last access 23.06.2019.
UNESCO adopted the "Convention for the Safeguarding of the Intangible Cultural Heritage" - which has so far been ratified by 178 State Parties -, "considering the importance of the intangible cultural heritage as a mainspring of cultural diversity and a guarantee of sustainable development" (https://ich.unesco.org/en/convention ${ }^{2}$ ), with the goal of safeguarding it against globalization and social transformation. UNESCO Conventions "demonstrate the importance, for all the peoples of the world, of safeguarding this unique and irreplaceable property, to whatever people it may belong" (https://whc.unesco.org/en/ conventiontext $/{ }^{3}$ ), since heritage is not a privilege of some, but is rather a resource for anyone.

Tourism might be both an opportunity and a threat for tangible and intangible heritage. On the one side, visiting and experiencing heritage allows both to discover and understand people's diversity, as well as to appreciate and promote own heritage, this way fostering inter-cultural conversations. On the other side, massive unmanaged tourism might ruin tangible sites, commodify intangible traditions, and challenge the relationship between locals and their heritage.

2 Last access 24.06.2019.

3 Last access 24.06.2019. 


\section{Topics and participants}

Information and Communication Technologies (ICTs) might play a key role in communicating heritage to global audiences of travelers, thanks to their pervasiveness and ease of use. The contributors to this panel discussed this issue, considering cases that helped to point out some major topics, in particular: the use of mobile applications to support travelers' planning and experience on site, cultural localization of online information to widen access to heritage understanding, online communication planning to closely connect locals and tourists with heritage, ICTs to develop new approaches to heritage destination stewardship.

The introductory talk by Silvia De Ascaniis and Lorenzo Cantoni (USI - Università della Svizzera italiana) was entitled "Mobile applications for travelers along cultural routes: striving to communicate the whole while presenting its parts". In 1987 the Council of Europe launched the Cultural Routes program, aiming at creating a transnational network of routes to be followed by travelers across Europe to discover its rich and diverse heritage. This was in line with a current major trend of re-discovering routes of pilgrims, merchants, armies, and so on, a development strongly supported by ICTs (Cantoni et al., 2016; De Ascaniis et al., 2018). Currently, the program counts 31 routes; the first one to be chosen was the "Santiago de Compostela Pilgrim Routes" (1987), which is considered an illustration of European unification and identity, while the most recently certified one is the "Fortified Towns of the Greater Region" (2016). Each route is presented in a dedicated page on the official website, all of them have their own website, 19 ones have a Facebook page, 2 routes have a Twitter account, 1 route has an Instagram account and 1 has a blog. Official mobile applications were also developed for 4 routes: "Santiago de Compostela Pilgrim Routes", "Via Francigena", "European Route of Ceramics", and "The Hansa". In the conference presentation, an overview of the four mobile apps was given, arguing on the main challenge that the developers of such digital tools had to face: finding a balance between the need to present the route as a whole, while at the same time providing information and services about different parts of it. Such applications, and in general the communication by the Routes, has to present the structure of the rhetorical figure of synecdoche: they should (re)present the whole route in every single part of it. This is true for both the routes that are supposed to be done walking from one place to the other "syntagmatic" ones, like Camino di Santiago - as well as for the routes that cluster places that are not supposed to be visited one after the other within the same travelling experience - "paradigmatic" ones, like the European Route of Ceramics (Cantoni et al., 2009). A usability analysis (Cantoni, Di Blas \& Bolchini, 2003; Garrett, 2010) showed that the apps are mostly successful in helping travelers along the road not get lost and in guiding them to the main tourism and hospitality services (e.g. accommodation, attractions, means of transport). They are hardly useful, instead, when it comes to organizing the journey and providing a context for the meanings and values signified by the route.

Emanuele Mele (USI - Università della Svizzera italiana) then gave a talk on " $\mathrm{Lo}$ calization of Tourism marketing websites: a methodological proposal". Tourism has always been a highly globalized market. The implementation of ICTs and the Internet has further pushed that globalization, challenging online communication outlets to take care of very different audiences. This implies not only a need for linguistic translation, but also for a cultural one, especially when it comes to publics whose cultural background is very different from the one of the destination countries. Such cultural translation has been named 'localization'. This presentation aimed, on the one side, at providing a wide overview on the already existing studies about cultural localization in the field of tourism (Tigre Moura, Gnoth, \& Deans, 2014; Cappelli, 2008), on the other side at discussing how different theoretical approaches - especially those by Hofstede and colleagues (Hofstede, Hofstede, \& Minko, 2010) and 
by Hall (1976) - can be (or not) applied to this domain, their advantages and limitations. In this regard, a proposal was made on how to culturally map visuals in the field, taking into consideration not only the content of the pictures, but also other relevant parameters: level of zoom, miseen-scène, relationship among pictured persons, and between the viewer and the people in the picture itself.

Maria Emilia Garbelli (University of Milano-Bicocca) continued the panel's discussion with her presentation "Measuring perceptions of UNESCO's World Heritage Sites using Bloom's taxonomy: evidence from an online survey". When planning online communication strategies in the tourism industry, one of the most important aspects to be considered is the identification of the relevant information to communicate - i. e. the information that the audience perceives to be of value. Such identification is usually based on the tourism operators' points of view, who aim at promoting their offers in the most attractive way. Regardless, tourists' perception of a place is the key for a successful differentiation. UNESCO recognition of "World Heritage" awarded to a site represents an extraordinary differentiation opportunity, which might attract tourists from all over the world (Poria, Reichen \& Cohen, 2013; De Simone, Canale \& Di Maio, 2018), if adequately communicated. In this presentation, the author argued that a successful promotion of a WHS should start with a clear identification of the best sources of differentiation (values and information) to be communicated. To achieve this, it needs first to measure the level of knowledge people already have (De Bryyn \& Lilien, 2008; Chen, Wang \& Wang, 2010). The author conducted an online survey to measure the awareness people have of UNESCOWHSs in Lombardy region (Italy), an area that is rich in WHSs, as well as the global role of UNESCO and the perceived value of a WHS declaration according to them. Bloom's taxonomy (Krathwohl, 2002), which suggests organizing knowledge in stages, helped to develop the survey by moving from questions that determine whether people simply recall certain words (such as "UNESCO") and recognize some other items, or whether they precisely remember one or more WHSs. Results pointed out that there is a cognitive gap between the knowledge of the UNESCO brand and its actual mission and activities. Also, WHSs were hardly recognized as such, but their cultural and natural value was clearly perceived and considered of great relevance.

The presentation "Fighting overtourism with communication in World Heritage Sites" by Engelbert Ruoss (USI - Università della Svizzera italiana) concluded the panel. 'Overtourism' means "too many tourists" and is usually connected to mass tourism. It is considered a dramatic scenario endangering extraordinary heritage sites all over the world. Overtourism is not only having a negative impact on beautiful tourism destinations, but it also reflects the deep ambiguity between quantity and quality tourism. A tourism management policy defining clear limits regarding visitor numbers can lower the pressure on the heritage sites, but new strategies must also be implemented to solve the problem in the long term (Ruoss \& Alfarè, 2013). Since overtourism is directly linked to overcapacity in tourism business, infrastructure which increases tourism should be strictly limited, the quality of visitor experience guaranteed, and the benefit of local population assured. A new governance and management approach of tourism destinations could be a "heritage stewardship destination" model. It involves all principal actors and aims at creating value for locals and visitors, offering opportunities to jointly engage in maintenance and protection of their heritage, to improve their living standards and to share equally both costs and benefits. Communication and ICT tools could play a key role in the realization of such a concept of heritage stewardship destinations. The objectives of communication should be to: increase communication among local actors and conservation and tourism stakeholders; increase awareness regarding heritage values and the need to respect resident people; improve the behavior of tourists visiting a heritage site; promote alternative 
visits or events in periods of low pressure; and provide ICT tools for the interaction of actors, visitors, and destination management. ICT tools could include: online platforms for information exchange among actors; smartphone applications or GPS-based systems for tracking tourism movements and simultaneously informing visitors about limits, obstacles and alternatives before and during their visits; destination dedicated channels on social media providing information on tourism flows and carrying capacity-related issues.

\section{Conclusion and reflections}

The panel has helped to reflect onto a major emerging research sector within tourism: how it is communicated through ICTs (eTourism). In particular, it has stressed the issue of how such communication can ensure a better understanding of destinations and attractions on the side of addressees - a public growing in numbers and in variety of its origin. Nowadays, such communication must take into consideration also sustainability and responsibility: travelers should be aware of the fragility of heritage, hence invited to behave in sustainable and responsible ways.

While ICTs are already extensively used in this communication, further research and creativity is needed to extend such communication to reach further audiences effectively and efficiently, and to ensure a better (inter-)cultural communication.

\section{Panel overview}

\section{Panel title}

Communicating World Heritage to global audiences of travelers

\section{Panel organizers}

Lorenzo Cantoni, Silvia De Ascaniis (USI Università della Svizzera italiana)

Date and location

Saturday, $3^{\text {rd }}$ November 2019, 11:00-12:30

Villa Ciani, Room 015
Mobile applications for travelers along cultural routes: Striving to communicate the whole while presenting its parts.

De Ascaniis, S. (USI Università della Svizzera italiana, UNESCO Chair in ICT to develop and promote sustainable tourism in World Heritage Sites, Lugano, Switzerland)

Cantoni, L. (USI Università della Svizzera italiana, UNESCO Chair in ICT to develop and promote sustainable tourism in World Heritage Sites, Lugano, Switzerland)

Localization of tourism marketing websites: A methodological proposal.

Mele, E. (USI Università della Svizzera italiana, Institute of Digital Technologies for Communication (ITDxC), Lugano, Switzerland)

Measuring perceptions of UNESCO's World Heritage Sites using Bloom's taxonomy: Evidence from an online.

Garbelli, M.E. (University of Milano-Bicocca, DEMS Department of Economics, Management and Statistics, Milan, Italy)

Fighting overtourism with communication in World Heritage Sites.

Ruoss, E. (USI Università della Svizzera italiana, UNESCO Chair in ICT to develop and promote sustainable tourism in World Heritage Sites, Lugano, Switzerland)

\section{References}

Cantoni, L., De Ascaniis, S., Marchiori, E., \& Mele, E. (2016). Pilgrims in the digital age: A research manifesto. International Journal of Religious Tourism and Pilgrimage, 4(3), 1-5. doi:10.21427/D7Z120.

Cantoni, L., Di Blas, N., \& Bolchini, D. (2003). Comunicazione, qualità, usabilità. Milano: Apogeo.

Cantoni, L., Tardini, S., Inversini, A., \& Marchiori, E. (2009). From paradigmatic to syntagmatic communities: a socio-semiotic approach to the evolution pattern of online travel communities. In W. Hopken, U. Gretzel, \& R. Law (Eds.), Information and Communication Technologies in Tourism 2009 (pp. 13-24). Wien: Springer.

Cappelli, G. (2008). The translation of tourism-related websites and localization: 
problems and perspectives. Voices on Translation, RILA Rassegna Italiana di Linguistica Applicata, 1-2, pp. 97-115.

Chen, W., Wang, C., \& Wang, Y. (2010). Scalable influence maximization for prevalent viral marketing in large-scale social networks. In Proceedings of the $16^{\text {th }}$ ACM SIGKDD international conference on Knowledge discovery and data mining (pp. 1029-1038), ACM.

De Ascaniis, S., Gravari-Barbas, M., \& Cantoni, L. (2018). Tourism Management at UNESCO World Heritage Sites. Lugano, Switzerland: Università della Svizzera italiana.

De Bruyn, A., \& Lilien, G. L. (2008). A multi sage model of world-of-mouth influence through viral marketing. International Journal of Research in Marketing, 25(3), 151-163.

De Simone, E., Canale, R. -R., \& Di Maio, A. (2018). Do UNESCO World Heritage Sites influence international tourist arrivals? Evidence from Italian Provincial Data. Social Indicators Research, pp. 1-15.

Garrett, J. J. (2010). The elements of user experience: user-centered design for the web and beyond ( $2^{\text {nd }}$ edition). Pearson Education.
Hall, E. T. (1976). Beyond Culture. New York: Anchor Books.

Hofstede, G., Hofstede, G. J., \& Minkov, M. (2010). Cultures and Organizations: Software of the Mind. Revised and expanded $3^{\text {rd }}$ Edition. New York: McGraw-Hill USA.

Krathwohl, D. R. (2002). A revision of Bloom's taxonomy. An overview theory into practice. The Ohio State University.

Poria, Y., Reichel, A., \& Cohen, R. (2013). Tourists' perception of World Heritage Sites and its designation. Tourism Management, 35, 272-274

Ruoss, E., \& Alfarè, L. (2013). Sustainable Tourism as Driving Force for Cultural Heritage Sites Development. Planning, Managing and Monitoring Cultural Heritage Sites in South East Europe. CHERPLAN project report.

Tigre Moura, F., Gnoth, J., \& Deans, K. R. (2014). Localizing cultural values on tourism destination websites: the effects on users' willingness to travel and destination image. Journal of Travel Research, 54(4), 528-542. 
